\title{
Chemical Composition of Fruits of Some Important Chestnut Cultivars
}

\author{
Ümran Ertürk*, Cevriye Mert and Arif Soylu \\ Department of Horticulture; Faculty of Agriculture; Uludag University; Görükle Campus; Bursa 16059; Turkey
}

\begin{abstract}
In this study, chemical compositions of the fruits of some important domestic chestnut types and cultivars were investigated. They contained (g/100g dry matter basis) total carbohydrates $75.32-86.31$, total sugar $10.32-22.79$, invert sugar 0.08 - 1.25, starch 54.45 - 69.70, sucrose $8.86-21.28$, ash 1.02 - 3.22, crude cellulose 3.58 - 5.96, total fat 0.49 - 2.01, total protein 4.88 - 10.87. $\mathrm{Ca}, \mathrm{Mg}, \mathrm{Fe}, \mathrm{Mn}, \mathrm{Cu}, \mathrm{Zn}, \mathrm{P}, \mathrm{Na}$ and $\mathrm{K}$ contents were $(\mathrm{mg} / \mathrm{lO0g}) 43$ 230, 70 - 160, 0.4 - 5.7, 0.7 - 5.5, 0.6 - 3.8, 1.8 - 9.1, 107 - 191, 6 - 41, 761 - 1271, respectively.
\end{abstract}

Key words: Castanea sativa, Chestnut, Fruit Composition

\section{INTRODUCTION}

Anatolia in Turkey is the motherland and one of the oldest cultivation area of chestnut (Castanea sativa Mill.). Numerous genotypes and cultivars have been developed this during past. Turkey is one of the leading countries in the world with its annual production of 50000 tons. However, chestnut production has been decreasing day by day because of ink disease (Phytophthora cambivora) and chestnut blight (Cryphonectria parasitica) in the natural growing areas.

The term "bread tree" has been used in some places for chestnuts, which has been one of the fundamental nutrients used in human nutrition (Bounous et al., 2000). The fruit is rich in carbohydrates and low in fat content. This characteristic increases its use in diets. Chestnut is widely used as a food by cooking as well as in cake and candy industry (Anonymous, 2000). However, differences could be detected among the species and the cultivars with respect to their nutritional value. This fact should especially be considered in selection studies. In this way, the genotypes with higher nutritional value as well as high yield and other quality characteristics could be improved.

This work was carried out with the aim of determining the chemical composition of some selected important domestic cultivars and two foreign hybrid cultivars.

\section{MATERIALS AND METHODS}

In this work, the fruits of cultivars and genotypes belonging to the species Castanea sativa Mill., (Ayfer et al., 1988) and the foreign hybrid cultivars Maraval 74 (C. sativa $x$ C. crenata) and Marigoule 15 (C. sativa $x$ C. crenata) (Solignat et al., 1975) were used as below. 51205 (Sarıaşlama Clone - 2), 52509 (Sarışlama Clone - 3), 52112 (Vakit Kestanesi), 51314, 51315, 51112 (Mahmut Molla), 52214 (Haciömer), 51101 (Osmanoğlu), 63110 (Acemoğlu), 52104 (Sarı Kestane), 62309 (Firdola), 51301, 51209 (Osmanoğlu Clone - 2)

\footnotetext{
${ }^{*}$ Author for correspondence
} 
and 51206. The trees from which the fruits were collected were 23 years old, except Marigoule 15 and Maraval 74, which were 13 years old. The orchard soil was alluvial, clayey - loam type, saltless, slightly acid, mineral content level was good, and organic matter level was poor (Ertan et al., 1992). The climate is fairly mild, and annual rainfall is about $750-800 \mathrm{~mm}$. The trees were grown in a natural growing condition, and they were supported only by irrigation in drought seasons and sometimes mineral fertilizer. The fruits were harvested at the end of September through the middle of October. The samples of about $120-150 \mathrm{~g}$ fruit that were randomly sampled were squashed with a mortar after their outer shells and seed coat (testa) were removed and analysis were carried out. The dry matter contents of the samples were determined by drying them overnight in the hot-air oven at $105{ }^{\circ} \mathrm{C}$. Ash analysis was carried out by burning the sample in muffle furnace at $525{ }^{\circ} \mathrm{C}$ for $8 \mathrm{~h}$. Total protein quantity was calculated by multiplying the nitrogen content using Kjeldahl method by the coefficient 5.30 (AOAC, 1990). Crude cellulose quantity was determined according to the method reported in AOAC (1990). Total fat quantity was found after extraction with ether for $6 \mathrm{~h}$ in soxhelet device (AOAC, 1990). Dinitrophenol method was utilised in the analysis of total carbohydrates, total sugar and invert sugar (Ross, 1959) using the Beckman Du 530 model spectrophotometer. Starch quantity was calculated by multiplying the value obtained through subtracting the total sugars from total carbohydrates by the coefficient 0.94 . Mineral quantities were determined as described by Kacar (1972); the concentrations of iron (Fe), magnesium $(\mathrm{Mg})$, copper $(\mathrm{Cu})$, zinc $(\mathrm{Zn})$ and manganese $(\mathrm{Mn})$ were determined by atomic absorption spectrophotometer; phosphorus $(\mathrm{P})$ was determined by spectrophotometer; potassium $(\mathrm{K})$, sodium $(\mathrm{Na})$ and calcium $(\mathrm{Ca})$ were determined by flame photometer. However, analysis of minerals, total fat, crude protein, ash and crude cellulose were done in the second year of experiment. The results were given on dry matter basis.

\section{RESULTS AND DISCUSSION}

\section{Total carbohydrates}

Total carbohydrate quantities changed between 75.32 and $86.31 \mathrm{~g} / 100 \mathrm{~g}$ depending on cultivars, with a mean value of $80.73 \mathrm{~g} / 100 \mathrm{~g}$ (Table 1). The chestnut fruits generally contained high rates of carbohydrates; this was $86.26 \mathrm{~g} / 100 \mathrm{~g}$ in American chestnuts ( $C$. dentata Borkh.) (McCarthy and Meredith, 1988), $87.50 \mathrm{~g} / 100 \mathrm{~g}$ in the Chinese chestnuts (McCarthy and Meredith, 1988; Anonymous, 2003c) and $71.68-88.10 \mathrm{~g} / 100 \mathrm{~g}$ in European chestnuts (McCarthy and Meredith, 1988; Künsch et al., 1999; Bounous, 1999; Bounous et al., 2000; Anonymous, 2003a). This value changed nearly $16 \%$ in the different materials of $C$. sativa species (Bounous et al., 2000; Anonymous, 2003a). In this study, $11 \%$ difference was found among the cultivars and the hybrids of $C$. sativa species. Our findings are in accordance with those of the researchers.

\section{Total sugar}

Total sugar contents changed between 10.32 and $22.79 \mathrm{~g} / 100 \mathrm{~g}$ (Table 1). This range was similar to those obtained by Pinnavaia et al. (1993) and Bounous et al. (2000) which were $14.01-20.60$ $\mathrm{g} / 100 \mathrm{~g}$ and $20.38 \mathrm{~g} / 100 \mathrm{~g}$, respectively.

\section{Invert sugar}

The invert sugars of the cultivars were between 0.08 and $1.25 \mathrm{~g} / 100 \mathrm{~g}$ (Table 1). Pinnavaia et al. (1993) found the invert sugar quantity of the cultivars between 0.82 and $3.56 \mathrm{~g} / 100 \mathrm{~g}$. The invert sugar contents of the cultivars examined were somewhat lower than these values. However, the share of invert sugar in total sugars was quite low, often below $5 \%$.

\section{Starch}

Starch quantities ranged from 54.45 to 69.70 $\mathrm{g} / 100 \mathrm{~g}$ with regard to the cultivars (Table 1). The values found by most researchers were close to these ones, generally ranging from 49.60 to 65.40 $\mathrm{g} / 100 \mathrm{~g}$ in different species (Pinnavaia et al., 1993; Liu, 1993; Ferreria - Cardoso et al., 1993; Bounous et al., 2000). However, some researchers found the value lower $(29.80 \mathrm{~g} / 100 \mathrm{~g})$ (Üstün et al., 1999) or higher (Demiate et al., 2001) $(80 \mathrm{~g} / 100 \mathrm{~g})$ than these. A part of starch changes into sugars during storage, thus the ratio of sugars increases and that of starch decreases (Soylu et al., 1987).

\section{Sucrose}

The sucrose quantities of the cultivars changed between 8.86 and $21.28 \mathrm{~g} / 100 \mathrm{~g}$ (Table 1). Pinnavaia et al. (1993) found this value between 10.45 and $19.74 \mathrm{~g} / 100 \mathrm{~g}$; Künsch et al. (1999) 
determined it as $12.40 \mathrm{~g} / 100 \mathrm{~g}$. Our findings are in accordance with the results obtained from these studies carried out with the cultivars in the species C. sativa Mill.

\section{Ash quantity}

The ash content changed between 1.02 and 3.22 $\mathrm{g} / 100 \mathrm{~g}$ (Table 2). Many other researchers found this value between 0.83 and $4.92 \mathrm{~g} / 100 \mathrm{~g}$ in various species and genotypes (Brighenti et al., 1998; Üstün et al., 1999; Demiate et al., 2001; Anonymous, 2003a, 2003b, 2003c).

\section{Crude cellulose}

The crude cellulose quantities of the cultivars ranged from 3.58 to $5.96 \mathrm{~g} / 100 \mathrm{~g}$ (Table 2). Demiate et al. (2001) found the crude cellulose quantity in Brazilian cultivars (C. sativa) as 2.34 g/100g. McCarthy and Meredith (1988) determined the crude cellulose quantity in American, European and Chinese chestnuts between 1.00 and $2.00 \mathrm{~g} / 100 \mathrm{~g}$. Notable differences have been detected among the genotypes with respect to crude cellulose quantity.

Table 1 - Total Carbohydrates, Total and Invert Sugar, Starch and Sucrose Contents of the Cultivars of Chestnut

\begin{tabular}{|c|c|c|c|c|c|c|c|c|c|}
\hline \multirow[t]{2}{*}{ Cultivars } & \multicolumn{3}{|c|}{$\begin{array}{c}\text { Total Carbohydrates } \\
(\mathrm{g} / \mathbf{1 0 0 g})\end{array}$} & \multicolumn{3}{|c|}{$\begin{array}{c}\text { Total Sugar } \\
(\mathrm{g} / \mathbf{1 0 0 g})\end{array}$} & \multicolumn{3}{|c|}{$\begin{array}{l}\text { Invert Sugar } \\
(\mathrm{g} / 100 \mathrm{~g})\end{array}$} \\
\hline & I.year & II.year & Mean & I. year & II.year & Mean & I. year & II.year & Mean \\
\hline 51205 S.A* Clone-2 & 86.15 & 75.07 & 80.61 & 17.15 & 16.36 & 16.75 & 1.92 & 0.09 & 1.00 \\
\hline 52509 S.A*Clone- 3 & 79.42 & 77.09 & 78.25 & 26.98 & 12.50 & 19.74 & 0.62 & 0.30 & 0.46 \\
\hline 52112 & 86.50 & 69.76 & 78.13 & 12.16 & 12.16 & 12.16 & 0.22 & 2.29 & 1.25 \\
\hline 51314 & 82.27 & 79.82 & 81.04 & 21.43 & 13.43 & 17.43 & 0.11 & 0.22 & 0.16 \\
\hline 51315 & 78.29 & 80.41 & 79.35 & 28.95 & 12.96 & 20.95 & 0.81 & 0.10 & 0.45 \\
\hline 51112 & 82.58 & 78.40 & 80.49 & 23.80 & 9.93 & 16.83 & 0.79 & 0.20 & 0.49 \\
\hline 52214 & 78.75 & 85.34 & 82.04 & 17.35 & 12.97 & 15.16 & 0.74 & 1.70 & 1.22 \\
\hline 51101 & 86.42 & 79.94 & 83.18 & 11.09 & 9.56 & 10.32 & 1.08 & 0.80 & 0.94 \\
\hline 63110 & 84.62 & - & 84.62 & 22.79 & - & 22.79 & 0.38 & - & 0.38 \\
\hline 52104 & - & 77.14 & 77.14 & - & 12.91 & 12.91 & - & 0.09 & 0.09 \\
\hline 62309 & - & 80.31 & 86.31 & - & 15.85 & 15.85 & - & 0.70 & 0.70 \\
\hline 51301 & - & 81.35 & 81.35 & - & 11.84 & 11.84 & - & 0.30 & 0.30 \\
\hline 51209 & - & 75.32 & 75.32 & - & 17.12 & 17.12 & - & 0.10 & 0.10 \\
\hline 51206 & - & 75.72 & 75.72 & - & 15.05 & 15.05 & - & 0.08 & 0.08 \\
\hline Maraval 74 & - & 85.95 & 85.95 & - & 11.80 & 11.80 & - & 0.50 & 0.50 \\
\hline Marigoule 15 & - & 82.29 & 82.29 & - & 11.62 & 11.62 & - & 0.40 & 0.40 \\
\hline Cultivars & & & $\begin{array}{l}\text { Starch } \\
(\mathrm{g} / \mathbf{1 0 0 g})\end{array}$ & & & & $\begin{array}{l}\text { Sucro } \\
(\mathrm{g} / 10 \mathrm{C}\end{array}$ & & \\
\hline & I.ye & & II.year & Mea & & I.year & II.ye & & Mean \\
\hline 51205 S.A* Clone-2 & 63. & & 55.10 & 59.0 & & 14.46 & 15.4 & & 14.95 \\
\hline 52509 S.A*Clone- 3 & 48. & & 60.43 & 54.5 & & 25.04 & 11.5 & & 18.31 \\
\hline 52112 & 69. & & 51.99 & 60.8 & & 11.34 & 9.3 & & 10.34 \\
\hline 51314 & 57. & & 62.19 & 59.6 & & 20.25 & 12.4 & & 16.33 \\
\hline 51315 & 45. & & 63.30 & 54.4 & & 26.73 & 12.2 & & 19.47 \\
\hline 51112 & 54. & & 64.17 & 59.3 & & 21.85 & 9.2 & & 15.54 \\
\hline 52214 & 57. & & 66.42 & 62.0 & & 15.75 & 10.7 & & 13.22 \\
\hline 51101 & $69 .^{\circ}$ & & 65.40 & 67.5 & & 9.50 & 8.2 & & 8.86 \\
\hline 63110 & 57. & & - & $\mathbf{5 7 . 7}$ & & 21.28 & & & 21.28 \\
\hline 52104 & & & 60.37 & 60.3 & & - & 12.0 & & 12.05 \\
\hline 62309 & & & 66.23 & 66.2 & & - & 14.2 & & 14.24 \\
\hline 51301 & & & 65.33 & 65.3 & & - & 10.8 & & 10.84 \\
\hline 51209 & & & 54.99 & 54.9 & & - & 15.9 & & 15.99 \\
\hline 51206 & & & 57.02 & $\mathbf{5 7 . 0}$ & & - & 14.0 & & 14.07 \\
\hline Maraval 74 & & & 69.70 & 69.7 & & - & 10.6 & & 10.62 \\
\hline Marigoule 15 & & & 62.43 & 62.4 & & - & 10.5 & & 10.54 \\
\hline
\end{tabular}


Table 2 - Ash, Crude Cellulose, Total Fat and Total Protein Contents of the Cultivars of Chestnut

\begin{tabular}{l|c|c|c|c}
\hline Cultivars & $\begin{array}{c}\text { Ash } \\
(\mathbf{g} / \mathbf{1 0 0 g})\end{array}$ & $\begin{array}{c}\text { Crude Cellulose } \\
(\mathbf{g} / \mathbf{1 0 0 g})\end{array}$ & $\begin{array}{c}\text { Total Fat } \\
(\mathbf{g} / \mathbf{1 0 0 g})\end{array}$ & $\begin{array}{c}\text { Total Protein } \\
(\mathbf{g} / \mathbf{1 0 0 g})\end{array}$ \\
\hline 51205 S.A*Clone- 2 & 2.29 & 5.43 & 1.52 & 7.99 \\
52509 S.A*Clone- 3 & 2.68 & 4.65 & 0.92 & 8.43 \\
52112 & 2.90 & 5.96 & 0.51 & 10.87 \\
51314 & 2.27 & 4.65 & 0.60 & 6.07 \\
51315 & 1.99 & 5.32 & 0.49 & 8.29 \\
51112 & 2.59 & 3.94 & 1.30 & 4.88 \\
52214 & 2.61 & 4.72 & 0.64 & 5.23 \\
51101 & 2.01 & 4.47 & 2.01 & 5.39 \\
52104 & 2.23 & 5.24 & 1.17 & 6.43 \\
62309 & 2.92 & 4.92 & 0.73 & 8.73 \\
51301 & 1.02 & 4.05 & 1.02 & 6.43 \\
51209 & 2.56 & 4.80 & 1.44 & 6.71 \\
51206 & 2.69 & 4.68 & 0.78 & 7.37 \\
Maraval 74 & 2.44 & 3.58 & 1.61 & 5.88 \\
Marigoule 15 & 3.22 & 4.15 & 1.60 & 5.61 \\
\hline
\end{tabular}

* S.A: Sarıaşlama

\section{Total fat}

The total fat content of the samples ranged from 0.49 to $2.01 \mathrm{~g} / 100 \mathrm{~g}$ (Table 2). This value was found between 0.66 and $5.59 \mathrm{~g} / 100 \mathrm{~g}$ by some other researchers in the cultivars belonging to the species C. sativa Mill. (Ferreria - Cardoso et al., 1993; Brighenti et al., 1998; Üstün et al., 1999; Demiate et al., 2001; Sundriyal and Sundriyal, 2001; Anonymous, 2003a). Fat content was determined as $1.98 \mathrm{~g} / 100 \mathrm{~g}$ in the Chinese chestnuts (Anonymous, 2003c) and as $0.38 \mathrm{~g} / 100 \mathrm{~g}$ in some Australian cultivars (Anonymous, 2003b).

\section{Total protein}

Total protein quantity changed between 4.88 and $10.87 \mathrm{~g} / 100 \mathrm{~g}$, but it was between 5.23 and 8.73 $\mathrm{g} / 100 \mathrm{~g}$ in most of the samples (Table 2). This was reported between 3.43 and $13.28 \mathrm{~g} / 100 \mathrm{~g}$ by different researchers in $C$. sativa Mill. (Pinnavaia et al., 1993; Ferreria - Cardoso et al., 1993; Brighenti et al., 1998; Bounous, 1999; Üstün et al., 1999; Anonymous, 2003a). This range was narrower in the Chinese chestnuts being between 2.12 and $7.49 \mathrm{~g} / 100 \mathrm{~g}$ (McCarthy and Meredith 1988; Anonymous, 2003c).

\section{Mineral contents}

The mineral contents of the cultivars are given in Table 3. The cultivars contained different amounts of $\mathrm{Ca}, \mathrm{Mg}, \mathrm{Fe}, \mathrm{Mn}, \mathrm{Cu}, \mathrm{Zn}, \mathrm{P}, \mathrm{Na}$ and $\mathrm{K}$. These values were found as $43-230 \mathrm{mg} / 100 \mathrm{~g}, 70-160$ $\mathrm{mg} / 100 \mathrm{~g}, 0.4-5.7 \mathrm{mg} / 100 \mathrm{~g}, 0.7-5.5 \mathrm{mg} / 100 \mathrm{~g}$, $0.6-3.8 \mathrm{mg} / 100 \mathrm{~g}, 1.8-9.1 \mathrm{mg} / 100 \mathrm{~g}, 6.0-41.0$ $\mathrm{mg} / 100 \mathrm{~g}$ and $761-1271 \mathrm{mg} / 100 \mathrm{~g}$, respectively. $\mathrm{Ca}, \mathrm{Mg}, \mathrm{Zn}, \mathrm{P}$ and $\mathrm{K}$ contents of the cultivars were higher than the values reported by Ferreria Cardoso et al. (1993); Künsch et al. (1999); Bounous, (1999); Bounous et al. (2000); Anonymous, (2003a). Fe, Mn and P values of the cultivars were in good agreement with the data from Ferreria Cardoso et al. (1993); Künsch et al. (1999), Bounous, (1999); Üstün et al. 1999, Bounous et al. (2000); Anonymous, (2003a), Anonymous, (2003b).

From a general point of view, the chemical composition of chestnut may vary depending on the source from which the fruits were taken. However it can be stated that fruit of chestnut contained mainly carbohydrates, mostly in starch and sucrose form. In addition $\mathrm{Ca}, \mathrm{Mg}, \mathrm{P}$ and $\mathrm{K}$ contents of the fruits are fairly higher. 
Table 3 - Mineral Composition of the Cultivars of Chestnut

\begin{tabular}{|c|c|c|c|c|c|c|c|c|c|}
\hline Cultivars & $\begin{array}{c}\mathrm{Ca} \\
(\mathrm{mg} / \\
\mathbf{1 0 0 g})\end{array}$ & $\begin{array}{c}\text { Mg } \\
(\mathrm{mg} / \\
\mathbf{1 0 0 g})\end{array}$ & $\begin{array}{c}\mathrm{Fe} \\
(\mathrm{mg} / \\
100 \mathrm{~g})\end{array}$ & $\begin{array}{c}\text { Mn } \\
(\mathrm{mg} / \\
\text { 100g) }\end{array}$ & $\begin{array}{c}\mathrm{Cu} \\
(\mathrm{mg} / \\
\mathbf{1 0 0 g})\end{array}$ & $\begin{array}{c}\mathbf{Z n} \\
(\mathrm{mg} / \\
\mathbf{1 0 0 g})\end{array}$ & $\begin{array}{c}\begin{array}{c}P \\
(\mathrm{mg} /\end{array} \\
\mathbf{1 0 0 g})\end{array}$ & $\begin{array}{c}\mathrm{Na} \\
(\mathrm{mg} / \\
100 \mathrm{~g})\end{array}$ & $\begin{array}{c}\mathrm{K} \\
(\mathrm{mg} / \\
100 \mathrm{~g})\end{array}$ \\
\hline 51205 S.A*Clone- 2 & 72 & 90 & 2.4 & 3.4 & 3.7 & 5.5 & 162 & 9 & 1066 \\
\hline 52509 S.A*Clone- 3 & 203 & 150 & 0.9 & 2.8 & 3.8 & 9.1 & 179 & 37 & 1271 \\
\hline 52112 & 80 & 80 & 4.4 & 1.1 & 1.4 & 3.0 & 185 & 14 & 837 \\
\hline 51314 & 230 & 140 & 1.0 & 4.5 & 3.2 & 8.7 & 133 & 36 & 897 \\
\hline 51315 & 215 & 160 & 1.6 & 0.8 & 2.5 & 8.7 & 178 & 37 & 762 \\
\hline 51112 & 43 & 80 & 0.8 & 3.2 & 0.6 & 1.8 & 185 & 6 & 934 \\
\hline 52214 & 219 & 140 & 1.1 & 2.4 & 1.1 & 7.2 & 145 & 41 & 1105 \\
\hline 51101 & 54 & 70 & 3.0 & 2.0 & 0.6 & 2.6 & 107 & 14 & 1059 \\
\hline 52104 & 105 & 80 & 0.4 & 5.5 & 1.1 & 2.1 & 180 & 16 & 922 \\
\hline 62309 & 92 & 110 & 5.7 & 1.8 & 2.1 & 3.3 & 191 & 16 & 900 \\
\hline 51301 & 73 & 70 & 0.7 & 1.6 & 0.7 & 2.5 & 157 & 6 & 761 \\
\hline 51209 & 207 & 100 & 0.9 & 2.3 & 1.2 & 7.6 & 183 & 40 & 886 \\
\hline 51206 & 69 & 80 & 2.0 & 0.8 & 1.7 & 2.8 & 160 & 11 & 951 \\
\hline Maraval 74 & 101 & 70 & 4.0 & 0.7 & 0.6 & 1.8 & 169 & 13 & 917 \\
\hline Marigoule 15 & 66 & 80 & 2.4 & 2.3 & 0.6 & 2.8 & 174 & 11 & 871 \\
\hline
\end{tabular}

*S.A: Sarıaşlama

\section{RESUMO}

Neste estudo, a composição química das frutas domésticas importadas tipo castanha e seus cultivares foram investigados. Seu conteúdo (base da matéria seca de $\mathrm{g} / 100 \mathrm{~g}$ com base em matéria seca) carboidratos totais 75,32 - 86,31, açúcares total 10,32 - 22,79, açúcar invertido 0,08 - 1,25, amido 54,45 - 69,70, sacarose $8,86-21,28$, cinzas $1,02-3,22$, celulose bruta $3,58-5,96$, gordura total $0,49-2,01$ do total, proteína total 4,88 10,87. Ca, Mg, Fe, Mn, Cu, Zn, P, Na e k índice foi $(\mathrm{mg} / 100 \mathrm{~g}) 43-230,70-160,0,4-5,7,0,7$ $5,5,0,6-3,8,1,8-9,1,107-191,6-41,761$ 1271 , respectivamente.

\section{REFERENCES}

Anonymous (2000), "Dr. Decuypere's nutrient charts" nuts and seeds chart. Disp. in: http://www. healthalternatives2000.com/nut-seed-chart.

Anonymous (2003a), Danish food composition databank. Disp. in: http:// www.foodcomp.dk.

Anonymous (2003b), Nutritional value of chestnuts. Disp. in: http://www.Chestnutgrowers.com.au.

Anonymous (2003c), Nuts, chestnuts, Chinese, roasted. Disp. in: http://nutrition.about.com/library/foodfind/ blnutchestnutroast.htm.

Association of Official Agricultural Chemists (1990), Official Methods of Analysis. $15^{\text {th }}$ ed. Washington, DC: AOAC.
Ayfer, M.; Soylu, A.; Çelebioğlu, G.; Mermer, S. and Sağlam, H. (1988), Selection of chestnut cultivars (Castanea sativa Mill.) in Marmara Region-II. Bahçe, 15, 71-81. (In: Turkish with English summary).

Brighenti, F.; Campagnolo, M. and Bassi, D. (1998), Biochemical characterization of the seed in instinct chestnut genotypes $(C$. sativa). In: International Symposium on Chestnut, 2., Bordeaux. Proceedings ... Bordeaux, France.

Bounous, G. (1999), Among the Chestnut Trees in Cuneo Province. Edizioni Metafore via Carlo Emanuele, 15-12100 Cuneo.

Bounous, G.; Botta R. and Beccaro, G. (2000), The chestnut: the ultimate energy source nutritional value and alimentary benefits. Nucis, 9, 44-50.

Demiate, I. M.; Oetterer, M. and Wosiacki, G. (2001), Characterization of chestnut (Castanea sativa) starch for industrial utilization. Braz. Arch Biol. Techn., 44, 69-78.

Ertan, U.; Genç, C.; Özelkök, S. and Moltay, İ. (1992), Studies on important physiological disorders of some standard apple cultivars-I bitter pit. Bahçe, 21, 39-52. (In: Turkish with English summary).

Ferreria-Cardoso, J. V.; Fontainhas-Fernandes A. A. and Torres-Pereira, M.G. (1993), Nutritive value and technological characteristics of Castanea sativa Mill. fruits - comparative study of some Northeastern Portugal cultivars. In: International Congress on Chestnut, Spoleto. Proceedings... Spoleto, Italy.

Kacar, B. (1972), Bitki ve Toprağın Kimyasal Analizleri: II. Bitki Analizleri. A. Ü. Ziraat Fakültesi Yayınları n.: 453. A. Ü. Basımevi, Ankara. (In Turkish). 
Künsch, U.; Scharer, H.; Conedera, M.; Sassella, A.; Jermini, M. and Jelmini, G. (1999), Quality assessment of chestnut fruits. Acta Hort., 494, $119-122$.

Liu, L. (1993), The germplasm resources of chestnut in China. In: International Congress on Chestnut, Spoleto. Proceedings... Spoleto, Italy.

McCarthy, M. A. and Meredith, F.I. (1988), Nutrient data on chestnuts consumed in the United States. Econ. Bot., 42, 29-36.

Pinnavaia, G. G.; Pizzirani, S.; Severini, C. and Bassi, D. (1993), Chemical and functional characterization of some chestnut varieties. In: International Congress on Chestnut, Spoleto. Proceedings... Spoleto, Italy.

Ross, F. A. (1959), Dinitrophenol methods for reducing sugars.Potato Processing, In: Talburt, W. F. and Smith, O. (Eds.). A VI Publishing Comp. Connecticut. pp. 469-470.

Solignat G.; Chapa, J. and Verhac, A. (1975), Principales Varietes Fruitieres de Chataigniers cultivees en France. INRA Centre de Recherches de Bordeaux, Stat.de Recherches d' Arboriculture Fruitiere, Pont-de-La Maye 33, Publ. n.: 392.

Soylu, A.; Eriş, A. and Sermenli, T. (1987), Researches on the possibilities of using ethephon (2chloroethylphosphonic acid) to facilitate the harvesting of chestnuts. Publ. Uludağ Univ. n. 7-0080141, Bursa-Turkey. (In: Turkish with English summary).

Sundriyal, M. and Sundriyal, R. C. (2001), Wild edible plants of the Sikim Himalaya: nutritive values of selected species. Econ. Bot., 55, 377-390.

Üstün, N.; Tosun Y. and Serdar, Ü. (1999), Technological properties of chestnut varieties grown in Erfelek district of Sinop city. Acta Hort, 494, 107-110. 